\section{Elections}

A.t the annual general meeting, the election of Mr. J. B. Morgan as president for 1963 was announced. Mr. R. E. Green was elected honorary treasurer and the honorary secretaries, Mr. F. W. Kollaway and Miss R. K. Tobias, were re-elected. Dr. E. A. Maxwell was elected as editor in place of Prof. R. L. Goodstein, who remains honorary librarian. Mr. B. J. F. Dorrington and Dr. E. Kerr woro re-elected, and Mr. J. K. Backhouse, Miss E. M. Holman and Mr. C. Steole elected as honorary assistant secretaries. This represents an increase of two assistant secrotaries, which reflects the growing amount of work being undertaken by the Association; the annual subscription was raised to $30 s$. in order to finance the Association's commitments. Mr. N. De Q. Dodds was ro-elected as honorary assistant treasurer.
J. K. BACKHOUSE

\title{
THE DANISH ATOMIC ENERGY COMMISSION
}

$\mathrm{T}$ HE annual report of the activities of the Danish Atomic Energy Commission for the period April 1, 1961-March $31,1962 *$, consists of six chapters dealing respectively with the construction at the Risø Research Establishment; the recent work of the Establishment; international co-operation in the peaceful use of nuclear energy; geological surveys in Greenland and other activities; the technical and administrative organization of the Commission; and the financial accounts of the Commission. The text of Act 170 of May 16, 1962, on nuclear installations (atomic plants), the list of publications and of papers written by members of the staff during the year under review, and a map of the Risø Research Establishment, form annexes to the report.

Eight meetings were held by the Commission, and thirty-six by the Executive Committee during the year. There was no alteration in the membership of the Commission and all members were re-appointed for the period of three years commencing February 1, 1962, with the exception of Profs. J. Bøggild and H. H. Jensen, whose terms of office did not expire until February 1, 1963. The late Prof. Niels Bohr was chairman and Dr. H. P. Christenson vice-chairman of the Commission, with $\mathrm{Mr}$. H. H. Koch, permanent under-secretary of State, chairman of the executive committee. The staff on March 31, 1962, numbered 723, of which 495 were employed in the technical and scientific divisions. The workshop staff consisted of 41 people, including seven apprentices, under the direction of a superintendent, and the library staff of 14 people, headed by the librarian.

The Commission's research activities, which were considerably extended during 1959-60 when the large reactor $D R 3$ was completed, have continued to develop and have led in particular to the accomplishment of several joint research projects in co-operation with atomic energy establishments in various countries and with European joint enterprises. Irradiation experiments for the Dragon project have been carried out on certain steel samples in the research reactor $D R 2$, and work has continued on graphite and uranium irradiation experiments in co-operation with the United Kingdom Atomic Energy Authority.

In the physies department of the Establishment, which houses the meteorological station, the reactor $L R 1$, and the linear accelerator, a number of practical courses were held for students from the Technical University of Denmark, for students from the Universities of Arrthus and Copenhagen, for engineers employed in industry and for operators attached to the reactor $D R 2$. The linear accelerator was used for experimental irradiation for both industry and the department. In addition, the sterilization by irradiation of medical equipment, including blood transfusion sets, female catheters, artificial lungs and disposable hypodermic syringes, was undertaken for individual firms. The meteorological station continued its invostigation of the meteorological conditions in the lower layers of the atmosphere and the data collected were processed statistically. The neutron crystal spectrometer attached to the reactor $D R 2$ was used to measure the total

* Report on the Activities of the Danish Atomic Energy Commission for the Period from 1 April, 1961, to 31 March, 1962. Pp. 84. (Copenhagen: Danish A tomic Energy Commission, 1962.) cross-section of organic coolants. A start has been made on the construction of a triple-axis crystal spectrometer for solid-state physical examinations. A low-temperature laboratory is being built and measurements made on superconductive materials. Other work in solid-state physics includes the study of the transport properties of pure metals.

The electronics department was largely concerned with the development and assembly of instruments, but in addition a study was made of tunnel diodes and their use in nuclear instruments, especially discriminators. During the summers of 1961 and 1962 the airborne scintillometer developed by the electronics department was tried out with promising results by the Greenland Geological Survey. The reactor engineering department was occupied with the helium heat transmission experiments HTTC for the Dragon project, and the organic heat loop was completed. Activities in connexion with the deuterium moderated, organic cooled, reactor $(D O R)$ project, included the construction of fuel elements, the hot-cell facility and apparatus for experiments with some of the components for the primary cooling circuit. The reactor physics section, which consists of a theoretical reactor physics group, an experimental reactor physics group and a computer group, concentrated its attention on calculations and measurements in relation to the $D O R$ project. A major effort was made to prepare computer codes for use in $D O R$ calculations, and, during the year under review, codes were prepared for the calculation of the thermal utilization factor, resonance escape probability, fast-fission factor, and Fermi age. The main tool of the computer group is to be the digital computer GIER, which was produced by the Danish Institute of Computing Machinery and which was installed at the Risø Establishment during February 1962. The fast memory of GIER contains 1,024 words, each of 42 binary digits, and its magnetic drum memory contains 12,000 words. The addition time is 50 usec.

The results of the attempt by the chemistry department to obtain, by examination on a laboratory scale, suitable processes for a continuous extraction method for the utilization of the uranium and thorium deposits in Greenland were encouraging. In addition, calculations of the investment and operation costs of an extraction plant showed that the economic use of the deposits in the future is a possibility, and some 200 tons of ore were therefore mined and brought to Risø during 1962 for further experimentation. The radiolysis and pyrolysis of terphenyls, of importance in connexion with the $D O R$ project, were studied and the decay schemes for arsenic-78, metastable indium-116 and lanthanum-140 were investigated. The radiochemistry of proteins, the possibility of separation of uranium isotopes in a Ranque-Hilsch vortex tube, and the use of electron spin resonance are some of the other activities of the department mentioned in the report.

During the period under review, more than 6,000 people visited Risø and were shown around the Establishment on conducted tours. The scientific staff of the Commission have co-operated in the teaching at institutes of higher education and several physics courses have been held for primary school teachers and technical college teachers. 
In collaboration with the University Extension Commit. tee of the Technical University of Denmark a series of lectures entitled "Atomic Energy-its Implications and Utilization" have been given in Hjørring and Elsinore. The Library issued 24,014 items on loan during the year, and 2,045 books, periodicals and reports were borrowed from other libraries. On March 31, 1962, the total holding of the Library consisted of 95,000 bibliographical units, of which 30,000 were on microcards.

S. Weintroub

\section{RADIATION HAZARDS IN PERSPECTIVE}

$\mathrm{T}$ HE Expert Committee on Radiation of the World Health Organization consists of a group of international experts under the chairmanship of Lord Adrian. The Committee, together with representatives of several other organizations, met in Geneva during October 24-30, 1961 , to discuss the relative somatic and genetic effects of ionizing radiation and of other agents and substances in our environment which have toxic, carcinogenic or mutagenic properties. The report of that meeting has now been published *.

Prominence has been given in recent years to the hazards of ionizing radiation and intensive studies have been made of radiation injuries and elaborate protection measures devised. Emphasis, however, should also be given to the beneficial aspects of many procedures involv. ing radiation exposure, for it is well known that the benefits of the appropriate medical use of radiation in diagnosis and therapy far outweigh the hazards. With adequate protective measures, radioactive materials and nuclear energy can be peacefully and usefully applied in industrial and technological fields.

The report warns that preoceupation with the problems of radiation hazards may obscure the fact that there are many other toxic agents in the environment, some very widespread, which could prove a greater menace to public health. Man-made hazards to health must be reviewed against the background of known or unknown causes of disease, co-extensive with the whole field of medicine. In less-developed areas, man-made hazards account for only a small proportion of illness, but in highly developed areas they are responsible for a significant fraction of illness and death. The statistics given in the report show that in many countries accidents rank third as a cause of death and constitute the leading eause of death in the younger and more productive age groups. Most of the reported injuries caused by chemical toxins have occurred in industry, but increasing attention is being directed to the dangers of air pollution, pesticide residues in food, and food additives. A wide variety of chemical compounds are now known to be carcinogenic and others have been shown experimentally to be capable of genetic changes.

Turning to self-imposed hazards, the report states that it appears quite obvious that cigarette smoking or something closely associated with it is largely responsible for the high incidence of bronchiogenic carcinoma in certain

* World Health Organization. Technical Report Series. No. 248. Radiation Hazards in Perspective: Third Report of the Expert Committee on Radiation. Pp.
H.M.S.O., 1962.) countries. Some anomalies in the geographical distribution of lung cancer strongly suggest that other agents are partly responsible. The most substantial evidence appears to be the higher incidence in urban than in rural smokers. The medical use of radiation for therapy of non-malignant conditions and of diagnosis, where, in the early days of radiological practice, excessive doses may have been given, has occasionally been shown to lead to malignant disease, and there is still need for care and research in this field. The genetic effects of radiation, chemicals and temperature are discussed in some detail. The total incidenoe of hereditary diseases and defects in man may be estimated at about 6 per cent of all live births. The discovery recently that a surprisingly high frequency of defects in man are associated with anomalies of chromosome number or structural aberrations of the chromosomes suggest, since such types of abnormalities can be produced by radiation, that radiation hazard is more extensive than suspected before. The role of mutation in maintaining the hereditary burden in man is still under debate and an answer is likely to be arrived at very slowly. Mutations in all animals and plants occur naturally, and although the causes of these spontaneous mutations are not well understood, it is estimated that only a small fraction could be due to the natural background radiation to which all living things are exposed. There is no a priori reason for believing that ionizing radiation is the only, or even the main, environmental factor in the production of mutations. Some hundreds of chemical agents are known to be mutagenic, but none has been investigated in such detail as radiation. The report calls for more research to assess the genetic hazards of mutagenic chemicals and temperature.

In their concluding remarks, the Committee recommends that studies be undertaken to establish criteria for safe exposure-levels to toxic agents, both for individuals (as in the case of occupational exposure) and for populations (as in the case of pollution of water, food and air). The suggestions that certain chemical agents may have deleterious somatic and genetic effects similar to those producod by ionizing radiations should be investigated, and the international standards of statistical reporting of effects, damage, disability and death because of toxic materials should be improved. In addition, epidemiological and genetic studies of the effects of toxic materials should be made and intensive research stimulated on the mechanism of action of these materiais including their carcinogenic and genetic effects.

\section{TOBERMORITE GEL IN CONCRETE}

$\mathrm{T}$ OBERMORITE is now known to be the ehief cementing compound in hardened Portland cement and its structure largely determines the properties of concrete. When Portland cement is mixed with a limited amount of water, a plastic, mud-like material called 'cement paste' rosults ; it sets in a matter of hours, becoming reasonably firm, then continues to harden for a period of months, if not years. The hardened paste is the matrix into which the fine and coarse crushed rock or natural sand and gravel enter, thus forming the artificial rock called concrete. Stephen Brunauer, of the Portland Cement
Association, Illinois, discussed the role of tobermorite gel in concrete at a lecture to the Institute of Civil Engineers in London in July 1962 and a transcript appeared in Structural Concrete (1, 7; January/February, 1963); this has since been reprinted for the Cement and Concrete Association, London.

Brunauer's thesis is briefly as follows. Portland cement is a complex mixture of oight or more compounds of which the two most important are known to be tricalcium silicate $\left(\mathrm{Ca}_{3} \mathrm{SiO}_{5}\right)$ and $\beta$-dicalcium silicate $\left(\beta-\mathrm{Ca}_{2} \mathrm{SiO}_{4}\right)$, these two silicates constituting about 75 per cent of an 